\title{
Biological, Serological, and Molecular Variabilities of Clover Yellow Vein Virus
}

\author{
Takahide Sasaya, Tokurou Shimizu, Yuzo Nozu, Masamichi Nishiguchi, Narinobu Inouye, and Hiroki Koganezawa
}

First, second, and sixth authors: Shikoku National Agricultural Experiment Station, Zentsuji, Kagawa 765, Japan; third and fourth authors: National Institute of Agrobiological Resources, Tsukuba, Ibaraki 305, Japan; and fifth author: Research Institute for Bioresources, Okayama

University, Kurashiki, Okayama 710, Japan.

Accepted for publication 30 June 1997.

\begin{abstract}
Sasaya, T., Shimizu, T., Nozu, Y., Nishiguchi, M., Inouye, N., and Koganezawa, H. 1997. Biological, serological, and molecular variabilities of clover yellow vein virus. Phytopathology 87:1014-1019.

A comparative study was made on the host reactions, serological properties, and nucleotide sequences of the coat protein (CP) gene of 10 clover yellow vein virus (ClYVV) isolates and one bean yellow mosaic virus (BYMV) isolate collected from different host plant species and locations in Japan. Two strains of ClYVV isolates, grouped on the basis of host reactions on Chenopodium amaranticolor, C. quinoa, Nicotiana clevelandii, N. benthamiana, Vicia faba, and Trifolium repens, corresponded to two serotypes determined by double-antibody sandwich- and triple-antibody sandwich-enzyme-linked immunosorbent assay using three polyclonal and nine monoclonal antibodies. These results were also con-

firmed by nucleotide sequence analysis of the $\mathrm{CP}$ gene. The $\mathrm{CP}$ gene of CIYVV isolates of strain 1, including the Australian isolate CIYVV-B, had 93 to $98 \%$ nucleotide identities and 97 to $99.6 \%$ amino acid identities. The CP of CIYVV isolates of strain 2, including the New Zealand isolate ClYVV-NZ, had 92 to $98 \%$ nucleotide identities and 95 to $98 \%$ amino acid identities. The nucleotide identities and the amino acid identities between the two ClYVV strains were 82 to $84 \%$, and 90 to $94 \%$, respectively. When compared with the CP sequences of $12 \mathrm{ClYVV}$ isolates, the CP sequence of the BYMV isolate had 71 to $73 \%$ nucleotide identity and 73 to $77 \%$ amino acid identity. Amino acid sequence differences among ClYVV isolates from strains 1 and 2 were located mostly at the N-terminal regions of the CP. Our results indicated that the ClYVV isolates studied could be separated into two strains on the basis of host reactions, serology, and the nucleotide sequence of the $\mathrm{CP}$ gene.
\end{abstract}

Clover yellow vein virus (ClYVV), first isolated from white clover by Hollings and Nariani (16) in England, is distributed worldwide $(3,10,17,20,21)$ and causes severe diseases in many kinds of leguminous and ornamental plants $(9,10,19,27)$. ClYVV is a member of the bean yellow mosaic subgroup of the genus Potyvirus, which includes bean yellow mosaic virus (BYMV), pea mosaic virus, sweetpea mosaic virus, and white lupin mosaic virus (3, 13,24). The taxonomy of bean yellow mosaic subgroup viruses has been controversial, because their properties are very similar to one another. Some researchers considered ClYVV a strain of BYMV because (i) they have overlapping host ranges; (ii) they produce morphologically similar pinwheel cytoplasmic inclusions; and (iii) antisera against ClYVV strongly interreact with BYMV and vice versa $(3,4,21)$. The confusion regarding their taxonomic relations was resolved by comparing structural information of the coat protein $(\mathrm{CP})$ gene and the $3^{\prime}$-noncoding region $\left(3^{\prime}-\mathrm{NCR}\right)$ of the viral RNA. Nucleotide sequences of the CP gene of several ClYVV and BYMV isolates have been published $(6,7,12,28,34,35)$, and the sequences fell into distinct clusters, indicating that CIYVV and BYMV are distinct Potyvirus species (35).

In Japan, a virus from leguminous plants originally described as a necrotic strain of BYMV (BYMV-N) (20) is now considered to be ClYVV (9), and ClYVV was also described from Calanthe sp. (19). BYMV-N is, however, different from other CIYVV isolates in host reactions and serological properties $(20,27)$. These variabilities among CIYVV isolates and their relatedness to BYMV

Corresponding author: T. Sasaya; E-mail address: tsasaya@skk.affrc.go.jp

DDBJ (DNA Data Base of Japan) accession numbers for ClYVV-MB3, -92-3, -N, -I89-1, -90-1, -94-6, -P180, and BYMV-90-2 are from D89538 to D89545.

Publication no. P-1997-0822-01R

(C) 1997 The American Phytopathological Society have made it difficult to develop reliable diagnostic techniques for CIYVV. The determination of variability within CIYVV and the understanding of mechanisms and factors affecting this variability are also of considerable agronomic significance, particularly for developing resistance gene deployment strategies.

In this study, 10 CIYVV isolates and one BYMV isolate, collected from different hosts and locations in Japan, were compared by host reactions, serological properties, and the sequences of the CP gene in order to shed light on the variability of CIYVV. Our results clearly showed that the Japanese CIYVV isolates were classified into two strains by host reactions, serological properties, and the sequences of the $\mathrm{CP}$ gene.

\section{MATERIALS AND METHODS}

Virus isolates and host reaction. Isolates of the viruses studied and their original hosts are shown in Table 1. Each virus isolate was sap-inoculated mechanically to at least 12 plants of each species tested in the greenhouse at 22 to $25^{\circ} \mathrm{C}$. All plants not showing symptoms were tested 3 to 4 weeks after inoculation by back-inoculation to Chenopodium amaranticolor.

Production of monoclonal antibodies (MAbs). Three 5-weekold male BALB/c mice were immunized by intraperitoneal injection of $100 \mu \mathrm{g}$ of purified virions of ClYVV-90-1 or ClYVV-92-3 emulsified in Freund's complete adjuvant and were boosted 27 days later by an intravenous injection of the same amount of the purified virions in saline. At day 30, the spleen was removed and $0.9 \times 10^{8}$ cells were fused with the myeloma partner PAI using polyethylene glycol 4000. Selected hybridoma cells were cloned and injected into the peritoneal cavity of BALB/c mice for bulk production of MAbs (14).

Enzyme-linked immunosorbent assay (ELISA). Double-antibody sandwich (DAS)-ELISA tests with polyclonal antisera to ClYVV-90-1, ClYVV-92-3, and BYMV-90-2 (26,27), and triple- 
antibody sandwich (TAS)-ELISA tests with monoclonal antisera to ClYVV-90-1 and ClYVV-92-3 were used in this experiment. Experiments were conducted with crude extracts of virus-infected Nicotiana benthamiana or Vicia faba plants ground 1/100 (wt/vol) in phosphate-buffered saline-Tween (PBS-T) or with purified virus preparations at a final concentration of $1.0 \mu \mathrm{g} / \mathrm{ml}$ in the same buffer. A negative control (extract from noninfected N. benthamiana plants) was added on each plate. The MAbs (tissue culture supernatant diluted $1: 10^{2}$ or ascitic fluids diluted $1: 10^{4}$ ) and antimouse immunoglobulin $\mathrm{G}$ conjugated with alkaline phosphatase (Sigma Chemical Co., St. Louis) diluted 1:5 $\times 10^{3}$ were incubated for $1 \mathrm{~h}$ at $25^{\circ} \mathrm{C}$. Substrate was incubated for $1 \mathrm{~h}$ at $25^{\circ} \mathrm{C}$, and an absorbance value at $405 \mathrm{~nm}$ of the reaction was measured.

Sequencing of CIYVV-90-1, CIYVV-92-3, and BYMV-90-2. ClYVV-90-1, ClYVV-92-3, and BYMV-90-2 were purified from infected broad bean leaves, and the viral RNAs were extracted as described by Uyeda et al. (35). Viral cDNAs were synthesized and unidirectionally ligated to Uni-ZAP XR lambda phage vector (Stratagene Inc., La Jolla, CA) at the EcoRI/XhoI site using a ZAP-cDNA synthesis kit (Stratagene Inc.) according to the manufacturer's instructions. Recombinant phage DNAs were encapsidated by a Gigapack Gold packaging extract (Stratagene Inc.) and amplified in Escherichia coli strain XL1-Blue MRF' according to the instructions provided by Stratagene Inc. Insert-bearing clones were identified by immunoscreening (18) using the antiserum to ClYVV-90-1 or BYMV-90-2. The selected lambda recombinants were converted to phagemids by in vivo excision according to the manufacturer's instructions (Stratagene Inc.). The clone CY9013 for ClYVV-90-1, the clone CY9233 for ClYVV-92-3, and the clone BY9021 for BYMV-90-2 were used for nucleotide sequencing. The plasmids were unidirectionally deleted by ExoIII/ mungbean-nuclease treatment (Promega Corp., Madison, WI). The nucleotide sequence was performed in both directions by the dideoxynucleotide chain termination procedure of Sanger et al. (25) using an Applied Biosystems 373A DNA sequencer (Perkin-Elmer Cetus, Foster City, CA). Multiple alignments of sequences were carried out using the program GENETYX-MAC (Software Development, Tokyo).

Sequencing of CIYVV-MB3, -N, -I89-1, -94-6, and -P180. Total nucleic acid extraction, reverse transcription, and polymerase chain reaction (PCR) were done as described (28). ClYVV-specific primers (5' CY-I: 5'-CGGGATCCTCAGAAGTCGCGTTGAAGAG$3^{\prime}$ corresponding to nucleotides 1 to 20 [28]; and 3' CY-I: 5'GCGGATCCGCTATAATAGTAAAACTTCG-3' corresponding to nucleotides 976 to 996 [28], BamHI site is underlined) were used to amplify the complete CP gene by PCR. The PCR was carried out using the following protocol: initial denaturation at $95^{\circ} \mathrm{C}$ for 3 min, and then 35 cycles of annealing $\left(60^{\circ} \mathrm{C}\right.$ for $\left.1 \mathrm{~min}\right)$, primer extension $\left(72^{\circ} \mathrm{C}\right.$ for $\left.1.5 \mathrm{~min}\right)$, and denaturation $\left(94^{\circ} \mathrm{C}\right.$ for $\left.1 \mathrm{~min}\right)$. Amplified DNA fragments were separated by electrophoresis in an agarose gel and isolated from the gel using the Prep-A-Gene DNA purification system (Bio-Rad Laboratories, Richmond, CA). After digestion with $B a m \mathrm{HI}$, the fragments were ligated to BamHI-digested pBluescript II KS(-) (Stratagene Inc.) using the Takara ligation kit (Takara, Tokyo) and transformed into E. coli strain XL1-Blue. Recombinant plasmids were identified by restriction enzyme analysis, and nucleotide sequencing was performed by the dideoxynucleotide chain termination procedure (25).

TABLE 1. The origin and host reactions of clover yellow vein virus (ClYVV) and bean yellow mosaic virus (BYMV) isolates in Japan

\begin{tabular}{|c|c|c|c|c|c|c|c|c|}
\hline \multirow[b]{2}{*}{ Isolate } & & \multirow[b]{2}{*}{ Original host } & \multicolumn{6}{|c|}{ Symptoms on } \\
\hline & & & $\begin{array}{c}\text { Nicotiana } \\
\text { benthamiana }\end{array}$ & $\begin{array}{l}\text { Nicotiana } \\
\text { clevelandii }\end{array}$ & $\begin{array}{l}\text { Chenopodium } \\
\text { amaranticolor }\end{array}$ & $\begin{array}{c}\text { Chenopodium } \\
\text { quinoa }\end{array}$ & $\begin{array}{l}\text { Vicia } \\
\text { faba }\end{array}$ & $\begin{array}{c}\text { Trifolium } \\
\text { repens }\end{array}$ \\
\hline \multirow[t]{10}{*}{ ClYVV- } & $90-1$ & Vicia faba & $\mathrm{CS} / \mathrm{Mo}, \mathrm{N}^{\mathrm{a}}$ & CS/Mo,NS & NS/Mo,Mal,N & NS/Mo,Mal,N & NS/M,N,LN & 1/Mo \\
\hline & MB3 & Vicia faba & $\mathrm{CS}, \mathrm{NS} / \mathrm{Mo}, \mathrm{N}$ & $(\mathrm{CS}) / \mathrm{Mo}$ & NS/Mo,Mal,N & NS/Mo,Mal,N & NS/M,N,LN & 1/Mo,NS \\
\hline & No30 & Phaseolus vulgaris & 1/Mo,NS & CS/Mo & NS/Mo,Mal,N & NS/Mo,Mal,N & NS/M,N,LN & 1/(Mo) \\
\hline & NFU & Phaseolus vulgaris & $\mathrm{CS} / \mathrm{Mo}, \mathrm{N}$ & $(\mathrm{CS}) /(\mathrm{Mo})$ & NS/Mo,Mal,N & NS/Mo,Mal,N & NS/M,N,LN & 1/Mo \\
\hline & $\mathrm{N}$ & Phaseolus vulgaris & $\mathrm{CS} / \mathrm{CS}, \mathrm{NS}$ & $\mathrm{CS} / \mathrm{CS}$ & NS/Mo,Mal,N & NS/Mo,Mal,N & NS/M,N,LN & 1/Mo \\
\hline & $\mathrm{NC}$ & Gentiana sp. & $\mathrm{CS}, \mathrm{NS} / \mathrm{Mo}, \mathrm{N}$ & $\mathrm{CS} /(\mathrm{Mo})$ & NS/Mo,Mal,N & NS/Mo,Mal,N & NS/M,N,LN & 1/Mo \\
\hline & I89-1 & Impatiens sultani & $\mathrm{CS}, \mathrm{NS} / \mathrm{Mo}, \mathrm{N}$ & $\mathrm{CS} /(\mathrm{Mo})$ & NS/Mo,Mal,N & NS/Mo,Mal,N & NS/M,N,LN & 1/Mo \\
\hline & $92-3$ & Vicia faba & $\mathrm{CS} / \mathrm{CS}$ & $\mathrm{CS} /-$ & $\mathrm{NS} /-$ & $\mathrm{NS} /-$ & NS/Mo,NS & $-1-$ \\
\hline & $94-6$ & Vicia faba & $\mathrm{CS} / \mathrm{CS}$ & $(\mathrm{CS}) /-$ & $\mathrm{NS} /-$ & $\mathrm{NS} /-$ & NS/Mo,NS & $-1-$ \\
\hline & $\mathrm{P} 180$ & Pisum sativum & $\mathrm{CS} / \mathrm{CS}$ & $\mathrm{CS} /-$ & $\mathrm{NS} /-$ & $\mathrm{NS} /-$ & NS/Mo,NS & $-1-$ \\
\hline BYMV- & $90-2$ & Vicia faba & $1 /-$ & $1 /-$ & CS/Mo & $\mathrm{CS} /-$ & 1/Mo & $-1-$ \\
\hline
\end{tabular}

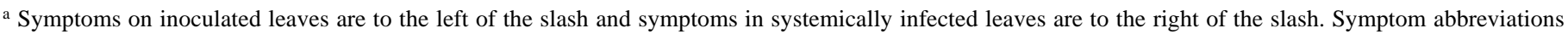
are -, no infection; 1, latent (symptomless) infection; CS, chlorotic spots; (CS), weak chlorotic spots; LN, lethal necrosis; Mal, malformation; Mo, mottle or mosaic; (Mo), weak mottle or mosaic; N, necrosis; and NS, necrotic spots.

TABLE 2. The serological variability of clover yellow vein virus (ClYVV) and bean yellow mosaic virus (BYMV) isolates in Japan as determined by doubleantibody sandwich-enzyme-linked immunosorbent assay (ELISA) and triple-antibody sandwich-ELISA

\begin{tabular}{|c|c|c|c|c|c|c|c|c|c|c|}
\hline \multirow[b]{3}{*}{ Isolates } & & \multirow{2}{*}{\multicolumn{3}{|c|}{ Polyclonal antiserum to }} & \multicolumn{6}{|c|}{ Monoclonal antibody to } \\
\hline & & & & & \multicolumn{4}{|c|}{ ClYVV-90-1 } & \multicolumn{2}{|c|}{ ClYVV-92-3 } \\
\hline & & ClYVV-90-1 & ClYVV-92-3 & BYMV-90-2 & $1 \mathrm{C} 8$ & $1 \mathrm{~A} 2^{\mathrm{a}}$ & 3G9 & $5 \mathrm{~F} 2$ & 5D6 & $3 \mathrm{H} 8^{\mathrm{b}}$ \\
\hline \multirow[t]{10}{*}{$\overline{C l Y V V-}$} & $90-1$ & $+++^{c}$ & ++ & ++ & +++ & +++ & +++ & ++ & + & - \\
\hline & MB3 & +++ & ++ & ++ & +++ & +++ & +++ & ++ & + & - \\
\hline & No30 & +++ & ++ & ++ & +++ & +++ & +++ & ++ & + & - \\
\hline & NFU & +++ & ++ & ++ & +++ & +++ & +++ & ++ & - & - \\
\hline & $\mathrm{N}$ & +++ & ++ & ++ & +++ & +++ & +++ & ++ & + & - \\
\hline & $\mathrm{NC}$ & +++ & ++ & ++ & +++ & +++ & +++ & ++ & - & - \\
\hline & I89-1 & +++ & ++ & ++ & +++ & +++ & +++ & ++ & - & - \\
\hline & $92-3$ & + & +++ & - & - & +++ & - & +++ & + & +++ \\
\hline & $94-6$ & ++ & +++ & - & - & +++ & - & ++ & + & +++ \\
\hline & P180 & + & +++ & - & - & +++ & - & ++ & + & +++ \\
\hline BYMV- & $90-2$ & + & + & +++ & - & - & ++ & ++ & - & - \\
\hline
\end{tabular}

a Results obtained with an additional monoclonal antibody, 2H8, were identical.

b Results obtained with two additional monoclonal antibodies, 2 D6 and 6F8, were identical.

${ }^{c}$ Serological reactivity, measured as the absorbance at $405 \mathrm{~nm}(\mathrm{~A})$ after $1 \mathrm{~h}$ of substrate incubation:,$- \mathrm{A}<0.05 ;+, 0.05<\mathrm{A}<0.5 ;++, 0.5<\mathrm{A}<1.5 ;$ and,$+++ \mathrm{A}>1.5$. 


\section{RESULTS}

Biological variability. While significant biological variabilities were observed among ClYVV isolates from Japan, the $10 \mathrm{ClYVV}$ isolates studied here were separated into two subsets (subset 1: 90-1, MB3, No30, NFU, N, NC, and I89-1; and subset 2: 92-3, 94-6, and P180) by the reactions of C. amaranticolor, C. quinoa,
$N$. benthamiana, N. clevelandii, V. faba, and T. repens (Table 1). ClYVV isolates in subset 1 induced systemic symptoms on $C$. amaranticolor, C. quinoa, and $N$. clevelandii. Those in subset 2 incited only local infection in these plants. The isolates in subset 1 induced systemic mosaic and necrotic symptoms on $N$. benthamiana, while those in subset 2 produced systemic chlorotic spots on this plant. On $V$. faba, the isolates in subset 1 induced systemic

\begin{tabular}{|c|c|c|}
\hline ClYVV- & $90-1$ & SDKEKLNAGE \\
\hline & MB 3 & $\ldots \ldots \ldots$ \\
\hline & No 30 & $\cdots \cdots \cdot v \cdots$ \\
\hline & NEU & $\cdots D \cdots \cdots$ \\
\hline & $\mathrm{N}$ & $\cdots \cdots s \cdots$ \\
\hline & $\mathrm{NC}$ & $\cdots \cdots \cdots D$ \\
\hline & I 89-1 & $\ldots \ldots \ldots$ \\
\hline & $\mathrm{B}$ & $\ldots \ldots \ldots \ldots$ \\
\hline & $92-3$ & $\cdot G \cdot Q \cdot \cdots$ \\
\hline & $94-6$ & $\cdot G \cdots Q \cdots \cdots$ \\
\hline & P180 & $\cdot G \cdot K Q \cdots \cdot$ \\
\hline & $\mathrm{NZ}$ & $\cdot G \cdot Q \cdots \cdot$ \\
\hline IMV- & $90-2$ & $\cdots Q \cdots \cdots \cdots$ \\
\hline
\end{tabular}

\begin{tabular}{|c|c|c|c|}
\hline ClYVV- & $90-1$ & NLDHLLVYVP & NQDDISNNIA \\
\hline & MB 3 & $\ldots \ldots \ldots$ & $\ldots \ldots \ldots$ \\
\hline & No3 3 & $\ldots \ldots \ldots$ & $\cdots \ldots \ldots$ \\
\hline & NEU & $\cdots \cdots \cdots$ & $\cdots \cdots \cdots$ \\
\hline & N & $\cdots G \cdots \cdots$ & $\cdots \cdots$ \\
\hline & $\mathrm{NC}$ & $\ldots \ldots \ldots$ & $\ldots \ldots$ \\
\hline & I 89-1 & $\ldots \ldots \ldots$ & $\ldots \ldots \ldots$ \\
\hline & B & $\cdots \ldots \ldots$ & $\ldots \ldots \ldots$ \\
\hline & $92-3$ & $\cdots \cdots \sqsubset \cdots$ & $\ldots \ldots \ldots$ \\
\hline & $94-6$ & $\cdots \cdots$ 一 $\cdots$ & $\cdots \cdots \cdots$ \\
\hline & P180 & $I \cdots \cdots$ I $\cdots$ & $\cdots \cdots \cdots$ \\
\hline & $\mathrm{NZ}$ & $\cdots \cdots \cdot I \cdots$ & $\cdots \cdots \cdots$ \\
\hline YMV- & $90-2$ & $\cdots \cdots \cdot D \cdot N \cdot$ & $\mathrm{p} \cdots \cdots \mathrm{*} \cdot$ \\
\hline
\end{tabular}

TQEQLEAWHE $\ldots \ldots \ldots$ $\ldots \ldots \ldots$ $\ldots \ldots \ldots$ $\cdots \mathrm{k} \cdots \cdots$ $\cdots \cdots \cdots$ $\ldots \ldots \ldots$ (n) $\cdots \cdots \cdots$ $\cdots A \cdot F \cdot Y Y N$
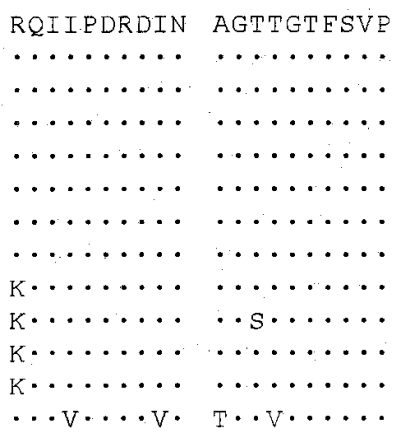

KLKKISGKLS $\ldots \ldots \ldots$ $\cdots \cdots \cdots$ $\ldots \ldots \ldots$ $\ldots \ldots \ldots$ $\ldots \ldots \ldots$ $\cdots \cdots \cdots$ ........ $\mathrm{T} \cdots \cdots$ $\mathrm{R} \cdots \cdots \cdots$ $\mathrm{T} \cdots \cdots \cdots$ $R \cdots \cdots \cdots$ $\cdots \mathrm{V} \cdot \cdots \mathrm{V}$.
LPTIRGKGLL - K・K・… $\cdots K \cdot K \cdot \cdots$ $\cdots \mathrm{K} \cdot \mathrm{K} \cdot \cdots$ $\cdots \mathrm{K} \cdot \mathrm{K} \cdot \cdots$ $\cdots K \cdot K \cdot \cdots$ $\cdots K \cdot K \cdot \cdots$ $\cdots K \cdot K \cdot \cdots$ $\cdots K \cdot K E \cdots$ $\cdots K \cdot K E \cdot \cdots$ $\cdots K \cdot K E \cdots$ $\cdots K \cdot K \cdot \cdots$ $I \cdot K \cdot G \cdot I V \cdot$

\begin{tabular}{|c|c|c|c|c|}
\hline VV- & $90-1$ & DGE KQVTFPL & KPILDEAKPT & LRQIMAH ESQ \\
\hline & MB3 & $\ldots \ldots \ldots$ & $\ldots \ldots \ldots$ & $\ldots \ldots \ldots$ \\
\hline & No30 & $\ldots \ldots \ldots$ & $\ldots \ldots \ldots$ & $\ldots \ldots \ldots$ \\
\hline & NEU & $\cdots \cdots \cdots \cdots$ & $\ldots \ldots \ldots$ & $\cdots \ldots \ldots$ \\
\hline & $\mathrm{N}$ & $\cdots D \cdots \cdots$ & $\ldots \ldots \ldots \ldots$ & $\cdots$ \\
\hline & NC & $\ldots \ldots \ldots \ldots$ & $\ldots \ldots \ldots$ & $\cdots$ \\
\hline & I89-1 & $\cdots_{N} \cdots \cdots$ & $\ldots \ldots \ldots$ & $\cdots$ \\
\hline & B & $\ldots \ldots \ldots$ & $\ldots \ldots \ldots$ & $\cdots \cdots \cdots$ \\
\hline & $92-3$ & $\cdots D \cdots \cdots \cdots$ & $\cdots v \cdots \cdots$ & $\cdots$ \\
\hline & $94-6$ & $\cdots D \cdots \cdots$ & $\cdots v \cdots \cdots$ & $\ldots \ldots$ \\
\hline & P.1 80 & $\cdots \mathrm{D} \cdots \cdots$ & $\cdots v \cdots \cdots$ & $\cdots \cdots \cdots F$ \\
\hline & N2 & $\cdots \mathrm{D} \cdots \cdots$ & $\cdots v \cdots \cdots \cdots$ & $\cdots \cdots$ \\
\hline & $90-2$ & $\cdots E \cdots Y Y$ & $\cdots N \cdots$ & $\cdots s$ \\
\hline
\end{tabular}
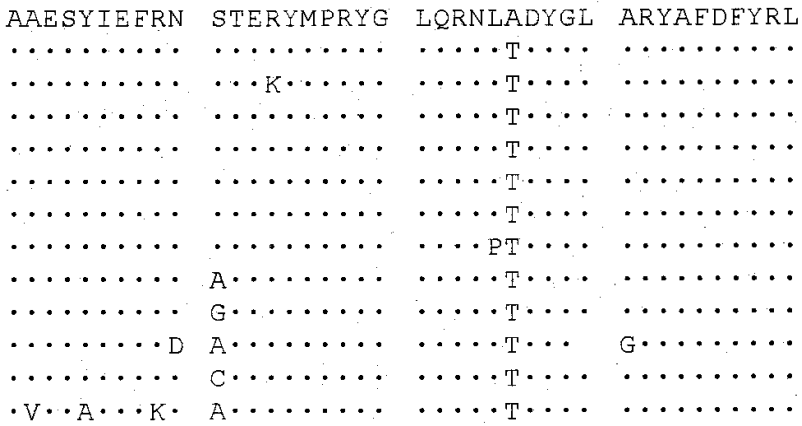

210

\begin{tabular}{|c|c|c|c|c|c|c|c|}
\hline \multirow[t]{12}{*}{ ClYVV- } & $90-1$ & TSKT PARARE & AHMQMKAAAI & RGKSNHMEGL & DGNVGT DEEN & TERHTANDVN & RNMHHIAGAR \\
\hline & MB3 & $\ldots \ldots \ldots$ & $\ldots \ldots \ldots$ & $\ldots \ldots \ldots$ & $\ldots \ldots \ldots$ & $\ldots \ldots \ldots$ & $\ldots \ldots$ \\
\hline & No30 & $\ldots \ldots \ldots$ & $\ldots \ldots \ldots$ & $\cdots \ldots \ldots$ & $\cdots \cdots \cdots$ & $\cdots \cdots \cdots$ & $\cdots \cdots$ \\
\hline & $\mathrm{NFU}$ & $\cdots \cdots \cdots$ & $\cdots \cdots \cdots$ & $\cdots \cdots \cdots$ & $\cdots \cdots \cdots$ & $\cdots \cdots \cdots$ & $\cdots \cdots$ \\
\hline & $\mathrm{N}$ & $\cdots \cdots \cdots$ & $\cdots \cdots \cdots$ & $\cdots \cdots \cdots$ & $\cdots \cdots \cdots \cdots$ & $\cdots \cdots \cdots$ & $\cdots \cdots \cdots$ \\
\hline & $\mathrm{NC}$ & $\ldots \ldots \ldots$ & $\ldots \ldots \ldots$ & $\ldots \ldots \ldots$ & $\cdots \cdots \cdots$ & $\cdots \cdots \cdots$ & $k \cdots \cdots \cdots$ \\
\hline & I $89-1$ & . . . . . & $\ldots \ldots \ldots$ & $\ldots \ldots \ldots$ & $\ldots \ldots \ldots$ & $\cdots \cdots$ & $\cdots \cdots$ \\
\hline & B & $\cdots \cdots \cdots$ & $\cdots \cdots \cdots$ & $\cdots \cdots \cdots$ & $\cdots \cdots \cdots \cdots$ & $\cdots \cdots \cdots$ & $\cdots \cdots$ \\
\hline & $92-3$ & $\cdots \cdots+\cdots$ & $\ldots \ldots \ldots$ & $\ldots \ldots \ldots$ & $\ldots \ldots \ldots$ & $\cdots$ & $\cdots$ \\
\hline & $94-6$ & $\cdots \cdots$ - $\cdots$ & $\cdots \cdots \cdots$ & $I \cdots \cdots \cdots$ & $\cdots \cdots \cdots \cdots$ & $\cdots \cdots \cdots$ & $\cdots \cdots \cdots$ \\
\hline & $\mathrm{P} 1.80$ & $\cdots \cdots+\cdots$ & $\cdots \ldots \ldots$ & $\cdots \cdots \cdots$ & $\cdots$ & & $\cdots \cdots$ \\
\hline & $\mathrm{NZ}$ & $\cdots \cdots+\cdots$ & $\cdots \cdots$ & $\cdots \cdots$ & $\cdots$ & & $\cdots$ \\
\hline & $90-2$ & $\cdots \cdots v \cdots$ & $\cdots \cdots \cdots v$ & $\cdots \cdot R L \cdots$ & $\cdots \cdots$ & $\theta$ & $\cdot \mathrm{D} \cdot \mathrm{TML} \cdot \mathrm{V} \cdot$ \\
\hline
\end{tabular}

Fig. 1. Alignment of deduced coat protein amino acid sequences of clover yellow vein virus (ClYVV) and bean yellow mosaic virus (BYMV) isolates from Japan, Australia, and New Zealand. The sequences of ClYVV-No30 (35), NFU (28), NC (28), B (34), and NZ (7) have been published. Amino acids of each isolate that differ from those of ClYVV-90-1 are indicated. 
mosaic and necrosis and a final lethal infection, while those in subset 2 induced systemic mosaic and necrotic spots on this plant. The isolates in subset 2 did not infect $T$. repens, which is an indicator plant for CIYVV and BYMV. Typically, ClYVV, but not BYMV, is capable of systemically infecting $T$. repens $(2,4,5,19)$.

Serological variability. The CIYVV and BYMV isolates in Japan were characterized serologically by DAS-ELISA using polyclonal antisera to ClYVV-90-1, ClYVV-92-3, and BYMV-90-2 (Table 2). All ClYVV and BYMV isolates reacted with the antisera to ClYVV-90-1 and ClYVV-92-3, but the isolates in subset 2 did not react with the antiserum to BYMV-90-2. Although all CIYVV and BYMV isolates reacted with the antisera to CIYVV90-1 and ClYVV-92-3, the reactivities among ClYVV and BYMV isolates were not identical. The isolates in subset 1 reacted more strongly with the antiserum to ClYVV-90-1 than did the isolates in subset 2 and BYMV-90-2. In contrast, the isolates in subset 2 reacted more strongly with the antiserum to ClYVV-92-3 than did the isolates in subset 1 , and BYMV-90-2 reacted weakly with the antiserum to ClYVV-92-3.

To obtain more information about the serological differences between the isolates in subsets 1 and 2, TAS-ELISA was performed using five MAbs to ClYVV-90-1 and four MAbs to CIYVV-92-3 (Table 2). TAS-ELISA using MAbs revealed differential reactivities among ClYVV and BYMV isolates, and none of these MAbs reacted with several other potyviruses such as pea seedborne mosaic virus, watermelon mosaic virus 2, lettuce mosaic virus, papaya ringspot virus $\mathrm{W}$-type, and potato virus $\mathrm{Y}$ (data not shown). One $\mathrm{MAb}$ (MAb-1C8) reacted only with the isolates in subset 1 . In contrast, three MAbs (MAb-3H8, MAb-2D6, and MAb-6F8) reacted only with the isolates in subset 2. Two MAbs (MA-1A2 and MAb-2H8) reacted with the isolates in both subsets, but did not react with BYMV-90-2. Although MAb-5D6 reacted with some CIYVV isolates in subset 1 and all CIYVV isolates in subset 2, their absorbance values were very low (Table 2). MAb-3G9 reacted with the isolates in subset 1 and BYMV-90-2, and MAb-5F2 reacted with all CIYVV and BYMV isolates.

Nucleotide sequence of the 3 '-terminal region of CIYVV-90-1, CIYVV-92-3, and BYMV-90-2. The complete sequences of clones CY9013 (ClYVV-90-1), CY9233 (ClYVV-92-3), and BY9021 (BYMV-90-2) were determined (data not shown). These sequences included part of the nuclear inclusion $b$ gene, the complete $\mathrm{CP}$ gene, and the entire 3 '-NCR. The 3'-NCR of both CIYVV-90-1 and CIYVV-92-3 were 175 nucleotides long, while that of BYMV-90-2 was 172 nucleotides. The 3'-NCR of ClYVV-92-3 had 94 and $73 \%$ nucleotide identity with the $3^{\prime}-\mathrm{NCR}$ of ClYVV-90-1 and BYMV-90-2, respectively.

Comparison of the CP gene of CIYVV and BYMV isolates. Synthetic primers $5^{\prime}$ CY-I and 3' CY-I were used to amplify the complete CP genes of five ClYVV isolates (MB3, N, I89-1, 94-6, and P180), and up to three clones of each isolate were sequenced (data not shown). The nucleotide sequences and the deduced amino acid sequences of these five $\mathrm{CP}$ genes were compared with the published data of the same regions of three other Japanese isolates, No30, NC, and NFU $(28,35)$, the Australian isolate ClYVV-B (34), and the New Zealand isolate ClYVV-NZ (7) (Fig. 1 and Table 3). The CP of 12 CIYVV isolates were identical in size (271 amino acids), whereas the CP of BYMV-90-2 was 273 amino acids, two amino acid residues longer. The CP of the isolates in subset 1 , including ClYVV-B, showed 93 to $98 \%$ nucleotide identity and 97 to $99.6 \%$ amino acid identity, whereas the $\mathrm{CP}$ of the isolates in subset 2, including ClYVV-NZ, showed 92 to $98 \%$ nucleotide identity and 95 to $98 \%$ amino acid identity. In contrast, the CP among the isolates in different subsets showed 82 to $84 \%$ nucleotide identity and 90 to $94 \%$ amino acid identity, and most of the nucleotide differences between subset 1 and subset 2 occurred in wobble bases (data not shown). However, the CP of BYMV-90-2 showed 71 to $73 \%$ nucleotide identity and 73 to $77 \%$ amino acid identity when compared with $12 \mathrm{CIYVV}$ isolates.

When the amino acid sequences of the CP among ClYVV isolates including CIYVV-B and ClYVV-NZ were compared, most of the differences were located in the N-terminal 31 amino acids, which is well-known to be the most variable region of the potyvirus $\mathrm{CP}(31,32)$ (Fig. 1 and Table 4). Among the isolates in the same subset, the N-terminal region of the $\mathrm{CP}$ appeared highly conserved (the amino acid identity was 87 to $100 \%$ ), but, among the isolates in different subsets, the $\mathrm{N}$-terminal region of the $\mathrm{CP}$ appeared diversified (the amino acid identity was 61 to $74 \%$ ). In contrast with the divergence of the $\mathrm{N}$-terminal region, the $\mathrm{C}$-terminal regions of these $12 \mathrm{ClYVV}$ isolates were highly conserved.

\section{DISCUSSION}

Taxonomy of the bean yellow mosaic subgroup of the genus Potyvirus has been confusing, because the viruses in this subgroup have many properties in common including host reactions and serological reactions $(3,4,21)$. For some time, CIYVV was considered a strain or a serotype of BYMV, because of an overlapping host range and strong serological interrelationships between ClYVV and BYMV $(3,4,20,21)$. In contrast, some ClYVV isolates have different biological and serological properties. Inouye (20) pointed out that two isolates of BYMV-N (later identified as CIYVV) have differences in pathogenicity. In our preliminary experiments, polyclonal antiserum to CIYVV-90-1 did not react with one of Inouye's BYMV-N isolates (P180) in sodium dodecyl sulfate agar double-diffusion tests (27).

In the current study, ClYVV isolates in Japan, collected from different hosts and locations, were largely classified into two subsets by host reactions and serological properties. Typical ClYVV

TABLE 3. Percent identities among coat protein nucleotide and amino acid sequences of clover yellow vein virus (CIYVV) and bean yellow mosaic virus (BYMV) isolates ${ }^{\mathrm{a}}$

\begin{tabular}{|c|c|c|c|c|c|c|c|c|c|c|c|c|c|c|}
\hline \multirow[b]{2}{*}{ Isolates } & & \multicolumn{12}{|c|}{ ClYVV- } & \multirow{2}{*}{$\frac{\text { BYMV- }}{90-2}$} \\
\hline & & $90-1$ & MB3 & No30 & $\mathrm{NFU}$ & $\mathrm{N}$ & $\mathrm{NC}$ & I89-1 & B & $92-3$ & $94-6$ & P180 & $\mathrm{NZ}$ & \\
\hline \multirow[t]{12}{*}{ ClYVV- } & $90-1$ & $\ldots$ & 97 & 96 & 96 & 96 & 96 & 96 & 93 & 82 & 82 & 83 & 83 & 72 \\
\hline & MB3 & 99 & $\ldots$ & 98 & 98 & 96 & 97 & 96 & 94 & 84 & 84 & 84 & 83 & 72 \\
\hline & No30 & 98 & 99 & $\ldots$ & 97 & 96 & 97 & 95 & 94 & 83 & 83 & 83 & 83 & 72 \\
\hline & NFU & 98 & 99.6 & 98 & $\ldots$ & 95 & 98 & 97 & 95 & 84 & 84 & 83 & 83 & 72 \\
\hline & $\mathrm{N}$ & 97 & 98 & 97 & 97 & $\ldots$ & 96 & 97 & 94 & 84 & 84 & 84 & 83 & 72 \\
\hline & $\mathrm{NC}$ & 98 & 99 & 98 & 98 & 97 & $\ldots$ & 96 & 94 & 84 & 83 & 83 & 82 & 73 \\
\hline & I89-1 & 98 & 99 & 98 & 99 & 98 & 98 & $\ldots$ & 94 & 84 & 83 & 84 & 83 & 72 \\
\hline & B & 97 & 98 & 97 & 98 & 97 & 98 & 98 & $\ldots$ & 83 & 83 & 83 & 82 & 72 \\
\hline & $92-3$ & 93 & 94 & 93 & 94 & 93 & 93 & 93 & 93 & $\ldots$ & 98 & 98 & 94 & 72 \\
\hline & $94-6$ & 92 & 93 & 92 & 93 & 92 & 92 & 92 & 93 & 98 & $\ldots$ & 96 & 94 & 72 \\
\hline & P180 & 90 & 92 & 90 & 92 & 91 & 91 & 91 & 91 & 98 & 96 & $\ldots$ & 92 & 71 \\
\hline & $\mathrm{NZ}$ & 93 & 94 & 93 & 93 & 93 & 93 & 93 & 93 & 97 & 97 & 95 & $\ldots$ & 72 \\
\hline BYMV- & $90-2$ & 77 & 77 & 77 & 77 & 76 & 77 & 77 & 77 & 76 & 75 & 73 & 76 & $\ldots$ \\
\hline
\end{tabular}

a Identities are presented for a coat protein amino acid sequence (below the diagonal) and for a coat protein nucleotide sequence (above the diagonal). 
infects $C$. quinoa, $N$. clevelandii, and $T$. repens systemically, and these plants were used for the indicator host plants of CIYVV $(2,4,5,17,19)$. ClYVV isolates in subset 1 systemically infected these plants, but those in subset 2 incited local infection or no infection on these plants. The host reactions incited by the isolates in subset 2 were closer to those of the BYMV isolate than to those of the isolates in subset 1 . In contrast with the similarity of the host reaction between the isolates in subset 2 and the BYMV isolate, those in subset 2 were serologically closer to the isolates in subset 1 than to BYMV. The polyclonal antiserum to BYMV-90-2 reacted moderately with the isolates in subset 1 and did not react with those in subset 2.

When the nucleotide and amino acid sequences of the $\mathrm{CP}$ gene were compared, CIYVV isolates in Japan also could be divided into two subsets, and the molecular variations of the $\mathrm{CP}$ gene were well correlated with biological and serological variabilities of ClYVV. $\mathrm{CP}$ sequence comparisons are widely accepted as the molecular basis of distinction between different Potyvirus species, and it is well established that $\mathrm{CP}$ amino acid sequence identities range from 38 to $70 \%$ among different Potyvirus species, and 90 to $99 \%$ among strains of the same Potyvirus species (11,31-33). The amino acid identities between the $\mathrm{CP}$ of viruses in subsets 1 and 2 are above the threshold of $90 \%$ identity, indicating that the viruses in subset 2 are isolates of ClYVV and not a different Potyvirus species. As mentioned above, the identities of $\mathrm{CP}$ amino acid sequences among different Potyvirus species so far reported are less than $70 \%$. That between ClYVV and BYMV, however, was 73 to $77 \%$. Therefore, differences between these two viruses are smaller than those between other Potyvirus species.

We propose that the two subsets of Japanese ClYVV isolates described here actually comprise two strains, according to Barnett's definition (1). The existence of different strains of ClYVV has been reported not only in Japan, but also in other countries. Barnett et al. (3) reported that CIYVV isolates from Australia were closely related to each other and distantly related to the Canadian isolate (ClYVV-Pratt) on the basis of molecular hybridization using random cDNA probes to the whole CIYVV genome and ELISA using polyclonal antibodies to BYMV and ClYVV. High-performance liquid chromatography peptide profiles have also been used to show that the CP sequences of ClYVV isolates from the United States and Australia were very similar to each other and more distant to the Canadian isolate (23). Host range and nucleotide sequence comparisons of the isolates of strain 1 and the Australian isolate ClYVV-B (34) indicated that ClYVV-B may be considered a member of strain 1 , although its serological properties have not been compared with those of the Japanese CIYVV isolates. Although the nucleotide sequence identity between the New Zealand isolate CIYVV-NZ (7) and the isolates of strain 2 indicated that CIYVV-NZ should be considered as strain 2, host range of CIYVV-NZ differed from that of the isolates of strain 2. In fact, the ClYVV-NZ isolate possesses a host range and serological properties similar to those of ClYVVPratt (10). Thus, the tentative classification of the Japanese CIYVV isolates reported in this paper cannot be applied directly to the New Zealand and Canadian isolates. More detailed experiments are needed to clarify the relationships among ClYVV isolates of strain 2, the New Zealand isolate, and the Canadian isolate.

Although it is now well established that strains of the same Potyvirus species have above $90 \%$ amino acid identity in the CP region, no clear sequence thresholds exist to delineate given isolates as distinct strains of a virus in support of biological or serological evidence. One approach to circumvent this problem was to compare the $\mathrm{N}$-terminal region of the $\mathrm{CP}$ (39). Xiao et al. (38) reported that comparison of the $\mathrm{N}$-terminal region of seven sugarcane mosaic virus strains revealed five different sequence patterns, and these could be grouped into three subsets that correlated with the host ranges of the strains. In this study, the amino acid variability of the ClYVV CP was particularly evident in the $\mathrm{N}$-terminal region of the CP. The amino acid identities of the $\mathrm{N}$-terminal region among ClYVV isolates of each strain ranged from 87 to $100 \%$, whereas a range of 61 to $74 \%$ identity was found between ClYVV isolates from different strains. Similar divergences have been reported in the $\mathrm{N}$-terminal region between different biological strains of bean common mosaic virus (22), plum pox virus $(8,37)$, and potato virus $\mathrm{Y}(36)$. These results strongly suggest that divergence in the N-terminal region may provide a reliable criterion to establish Potyvirus strain relationships, and that distinct potyvirus strains may be identified by some degree of the divergence in the $\mathrm{N}$-terminal region.

The existence of different types of ClYVV has sometimes led to difficulty in classifying these isolates with respect to their strain designations, and hampered the development of reliable diagnostic techniques of ClYVV. Our results revealed the serological variabilities of CIYVV isolates in Japan and demonstrated that MAbs can distinguish CIYVV from other bean yellow mosaic subgroup viruses (i.e., BYMV), and bean yellow mosaic subgroup viruses (ClYVV and BYMV) from several other potyviruses. MAb-1A2 and MAb-2H8 reacted with all CIYVV isolates tested, but did not react with $\mathrm{BYMV}$ and other potyviruses, indicating that there is at least one epitope unique to ClYVV. MAbs 1C8, 3H8, 2D6, and 6F8 were both strain-specific and ClYVV-specific. MAb-5F2 defined an epitope common to both the ClYVV and BYMV isolates used in this study. This confirms the close relationship of CIYVV with BYMV $(3,4,21)$, but also showed that there is a serological difference of at least three epitopes in the CP of ClYVV and BYMV isolates.

It is well-known that virus-specific epitopes are generally located in the variable N-terminal region of potyviral CPs $(15,29$, 30). Hewish et al. (15) reported that epitopes for CIYVV-specific MAbs were located in the N-terminal region of the ClYVV CP, whereas epitopes for potyvirus cross-reactive MAbs were located

TABLE 4. Percent identities among amino acid sequences in the hypervariable region (residues 1 to 31 ) of the coat protein of clover yellow vein virus (ClYVV) and bean yellow mosaic virus (BYMV) isolates

\begin{tabular}{|c|c|c|c|c|c|c|c|c|c|c|c|c|c|c|}
\hline \multirow{2}{*}{ Isolates } & & \multicolumn{12}{|c|}{ CIYVV- } & \multirow{2}{*}{$\frac{\text { BYMV- }}{90-2}$} \\
\hline & & $90-1$ & MB3 & No30 & NFU & $\mathrm{N}$ & $\mathrm{NC}$ & I89-1 & B & $92-3$ & $94-6$ & P180 & $\mathrm{NZ}$ & \\
\hline ClYVV- & $90-1$ & $\ldots$ & 97 & 97 & 94 & 94 & 94 & 100 & 94 & 71 & 71 & 68 & 65 & 45 \\
\hline & MB3 & & $\ldots$ & 94 & 97 & 90 & 90 & 97 & 90 & 74 & 74 & 71 & 65 & 45 \\
\hline & NFU & & & & $\ldots$ & 87 & 87 & 94 & 87 & 71 & 71 & 71 & 61 & 42 \\
\hline & $\mathrm{N}$ & & & & & $\ldots$ & 87 & 94 & 94 & 71 & 71 & 68 & 65 & 42 \\
\hline & $\mathrm{NC}$ & & & & & & $\ldots$ & 94 & 90 & 68 & 68 & 65 & 61 & 42 \\
\hline & $94-6$ & & & & & & & & & & $\ldots$ & 97 & 90 & 42 \\
\hline & P180 & & & & & & & & & & & $\ldots$ & 87 & 39 \\
\hline & $\mathrm{NZ}$ & & & & & & & & & & & & $\ldots$ & 39 \\
\hline BYMV- & $90-2$ & & & & & & & & & & & & & $\ldots$ \\
\hline
\end{tabular}


in the core region of the CP. Although we made no attempt to localize the epitopes recognized by our strain-specific MAbs, the variation in $\mathrm{N}$-terminal sequences of the CPs of our ClYVV isolates is consistent with a possible N-terminal location for the strainspecific epitopes.

In conclusion, ClYVV isolates in Japan could be grouped into two strains after comparison of their biological and serological properties. These results were also confirmed by nucleotide sequence analysis of the $\mathrm{CP}$ gene. Amino acid sequence differences among ClYVV isolates of different strains were located mostly at the Nterminal regions of the $\mathrm{CP}$.

\section{ACKNOWLEDGMENTS}

We thank I. Uyeda, H. Hagita, S. Nakamura, T. Natsuaki, and S. Osaki for supplying the clover yellow vein virus isolates, and C. Hiruki for critical review of the manuscript.

\section{LITERATURE CITED}

1. Barnett. O. W. 1992. A summary of potyvirus taxonomy and definitions. Arch. Virol. 5(Suppl.):435-444.

2. Barnett, O. W., and Gibson, P. B. 1975. Identification and prevalence of white clover viruses and the resistance of Trifolium species to these viruses. Crop Sci. 15:32-37.

3. Barnett, O. W., Randles, J. W., and Burrows, P. M. 1987. Relationships among Australian and North American isolates of the bean yellow mosaic potyvirus subgroup. Phytopathology 77:791-799.

4. Bos, L., Kowalska, C., and Maat, D. Z. 1974. The identification of bean mosaic, pea yellow mosaic and pea necrosis strains of bean yellow mosaic virus. Neth. J. Plant Pathol. 80:173-191.

5. Bos, L., Lindsten, K., and Maat, D. Z. 1977. Similarity of clover yellow vein virus and pea necrosis virus. Neth. J. Plant Pathol. 83:97-108.

6. Boye, K., Jensen, P. E., Stummann, B. M., and Henningsen, K. W. 1990. Nucleotide sequence of cDNA encoding the BYMV coat protein gene. Nucleic Acids Res. 18:4926.

7. Bryan, G. T., Gardner, R. C., and Forster, R. L. S. 1992. Nucleotide sequence of the coat protein gene of a strain of clover yellow vein virus from New Zealand: Conservation of stemloop structure in the $3^{\prime}$ region of potyviruses. Arch. Virol. 124:133-146.

8. Cervera, M. T., Riechmann, J. L., Martín, M. T., and García, J. A. 1993. 3'terminal sequence of the plum pox virus PS and Ô6 isolates: Evidence for RNA recombination within the potyvirus group. J. Gen. Virol. 74:329-334.

9. Chun, X. B., Ohki, S. T., Osaki, T., and Inouye, T. 1990. Clover yellow vein virus and a carlavirus isolated from Impatiens sultani in Japan. Ann. Phytopathol. Soc. Jpn. 56:557-560.

10. Forster, R. L. S., and Musgrave, D. R. 1985. Clover yellow vein virus in white clover (Trifolium repens) and sweet pea (Lathyrus odoratus) in the North Island of New Zealand. N.Z. J. Agric. Res. 28:575-578.

11. Frenkel, M. J., Ward, C. W., and Shukla, D. D. 1989. The use of 3' noncoding nucleotide sequences in the taxonomy of potyviruses: Application to watermelon mosaic virus 2 and soybean mosaic virus-N. J. Gen. Virol. 70:2775-2783.

12. Hammond, J., and Hammond, R. W. 1989. Molecular cloning, sequencing and expression in Escherichia coli of the bean yellow mosaic virus coat protein gene. J. Gen. Virol. 70:1961-1974.

13. Hampton, R. O., Shukla, D. D., and Jordan, R. L. 1992. Comparative potyvirus host range, serology, and coat protein peptide profiles of white lupin mosaic virus. Phytopathology 82:566-571.

14. Harlow, E., and Lane, D. 1988. Antibodies: A Laboratory Manual. Cold Spring Harbor Laboratory Press, Cold Spring Harbor, NY.

15. Hewish, D. R., Xiao, X. W., Mishra, A., Gough, K. H., and Shukla, D. D. 1993. Characterization and epitope analysis of monoclonal antibodies to virions of clover yellow vein and johnsongrass mosaic potyviruses. Arch. Virol. 133:127-141.

16. Hollings, M., and Nariani, T. K. 1965. Some properties of clover yellow vein, a virus from Trifolium repens L. Ann. Appl. Biol. 56:99-109.

17. Hollings, M., and Stone, O. M. 1974. Clover yellow vein virus. Commonw. Mycol. Inst./Assoc. Appl. Biol. (CMI/AAB) Descr. Plant Viruses 131.

18. Huynh, T. V., Young, R. A., and Davis, R. W. 1985. Constructing and screening cDNA libraries in $\lambda$ gt10 and $\lambda$ gt11. Pages $49-79$ in: DNA Cloning: A Practical Approach. Vol. 1. D. M. Glover, ed. IRL Press Limited, Oxford.

19. Inouye, N., Maeda, T., and Mitsuhata, K. 1988. A strain of clover yellow vein virus isolated from Calanthe sp. Acta Hortic. 234:61-68.

20. Inouye, T. 1968. Studies on host range of PVY-group viruses in leguminous plants in Japan and the identification of them by the selected differential test plants. Nougaku Kenkyu 52:11-29.

21. Jones, R. T., and Diachun, S. 1977. Serologically and biologically distinct bean yellow mosaic virus strains. Phytopathology 67:831-838.

22. Khan, J. A., Lohuis, D., Goldbach, R., and Dijkstra, J. 1993. Sequence data to settle the taxonomic position of bean common mosaic virus and blackeye cowpea mosaic virus isolates. J. Gen. Virol. 74:2243-2249.

23. McKern, N. M., Barnett, O. W., Whittaker, L. A., Mishra, A., Strike, P. M., Xiao, X. W., Ward, C. W., and Shukla, D. D. 1993. Sequence relationships among the coat proteins of strains of pea mosaic, white lupin mosaic, and bean yellow mosaic potyviruses. Phytopathology 83:355-361.

24. Randles, J. W., Davies, C., Gibbs, A. J., and Hatta, T. 1980. Amino acid composition of capsid protein as a taxonomic criterion for classifying the atypical S strain of bean yellow mosaic virus. Aust. J. Biol. Sci. 33:245-254.

25. Sanger, F., Nicklein, S., and Coulson, A. R. 1977. DNA sequencing with chain-terminating inhibitors. Proc. Natl. Acad. Sci. U.S.A. 74:5463-5467.

26. Sasaya, T., Iwasaki, M., and Yamamoto, T. 1993. Some properties of bean yellow mosaic virus (BYMV) isolated from broad bean (Vicia faba) and seed-transmission of BYMV in broad bean. Proc. Assoc. Plant Prot. Shikoku 28:15-22.

27. Sasaya, T., Iwasaki, M., and Yamamoto, T. 1994. Some properties of clover yellow vein virus (CYVV) isolated from a broad bean plant (Vicia faba). Proc. Assoc. Plant Prot. Shikoku 29:7-15.

28. Sasaya, T., Kaji, K., Fujisawa, I., Koganezawa, H., Teraoka, T., Natsuaki, T., and Okuda, S. 1997. Characterization and nucleotide sequence of the 3'terminal region of clover yellow vein virus isolated from gentian (Gentiana sp.) causing gentian necrotic dwarf. Ann. Phytopathol. Soc. Jpn. 63:328333.

29. Shukla, D. D., Strike, P. M., Tracy, S. L., Gough, K. H., and Ward, C. W. 1988. The $\mathrm{N}$ and $\mathrm{C}$ termini of the coat proteins of potyviruses are surface-located and the $\mathrm{N}$ terminus contains the major virus-specific epitopes. J. Gen. Virol. 69:1497-1508.

30. Shukla, D. D., Tribbick, G., Mason, T. J., Hewish, D. R., Geysen, H. M., and Ward, C. W. 1989. Localization of virus-specific and group-specific epitopes of plant potyviruses by systematic immunochemical analysis of overlapping peptide fragments. Proc. Natl. Acad. Sci. U.S.A. 86:8192-8196.

31. Shukla, D. D., and Ward, C. W. 1988. Amino acid sequence homology of coat proteins as a basis for identification and classification of the potyvirus group. J. Gen. Virol. 69:2703-2710.

32. Shukla, D. D., and Ward, C. W. 1989. Structure of potyvirus coat proteins and its application in the taxonomy of the potyvirus group. Adv. Virus Res. 36:273-314.

33. Shukla, D. D., and Ward, C. W. 1989. Identification and classification of potyviruses on the basis of coat protein sequence data and serology. Arch. Virol. 106:171-200.

34. Tracy, S. L., Frenkel, M. J., Gough, K. H., Hanna, P. J., and Shukla, D. D. 1992. Bean yellow mosaic, clover yellow vein, and pea mosaic are distinct potyviruses: Evidence from coat protein gene sequences and molecular hybridization involving the 3' non-coding regions. Arch. Virol. 122:249-261.

35. Uyeda, I., Takahashi, T., and Shikata, E. 1991. Relatedness of the nucleotide sequence of the 3 '-terminal region of clover yellow vein potyvirus RNA to bean yellow mosaic potyvirus RNA. Intervirology 32:234-245.

36. van der Vlugt, R. A. A., Leunissen, J., and Goldbach, R. 1993. Taxonomic relationships between distinct potato virus $\mathrm{Y}$ isolates based on detailed comparisons of the viral coat proteins and $3^{\prime}$-nontranslated regions. Arch. Virol. 131:361-375.

37. Wetzel, T., Candresse, T., Ravelonandro, M., Delbos, R. P., Mazyad, H., Aboul-Ata, A. E., and Dunez, J. 1991. Nucleotide sequence of the 3'terminal region of the RNA of the El Amar strain of plum pox potyvirus. J. Gen. Virol. 72:1741-1746.

38. Xiao, X. W., Frenkel, M. J., Teakle, D. S., Ward, C. W., and Shukla, D. D. 1993. Sequence diversity in the surface-exposed amino-terminal region of the coat proteins of seven strains of sugarcane mosaic virus correlates with their host range. Arch. Virol. 132:399-408.

39. Zerbini, F. M., Koike, S. T., and Gilbertson, R. L. 1995. Biological and molecular characterization of lettuce mosaic potyvirus isolates from the Salinas Valley of California. Phytopathology 85:746-752. 